\title{
Collagen gel droplet-embedded culture drug sensitivity testing in squamous cell carcinoma cell lines derived from human oral cancers: Optimal contact concentrations of cisplatin and fluorouracil
}

\author{
KANAME SAKUMA $^{1}$, AKIRA TANAKA ${ }^{1}$ and IZUMI MATAGA ${ }^{2}$ \\ ${ }^{1}$ Department of Oral and Maxillofacial Surgery, The Nippon Dental University School of Life Dentistry at Niigata, Niigata, \\ Niigata 951-8580; ${ }^{2}$ Department of Oral and Maxillofacial Surgery, The Nippon Dental University School of Life Dentistry, \\ Tokyo 102-8159, Japan
}

Received January 18, 2015; Accepted June 7, 2016

DOI: $10.3892 / \mathrm{ol} .2016 .5238$

\begin{abstract}
The collagen gel droplet-embedded culture drug sensitivity test (CD-DST) is an anticancer drug sensitivity test that uses a method of three-dimensional culture of extremely small samples, and it is suited to primary cultures of human cancer cells. It is a useful method for oral squamous cell carcinoma (OSCC), in which the cancer tissues available for testing are limited. However, since the optimal contact concentrations of anticancer drugs have yet to be established in OSCC, CD-DST for detecting drug sensitivities of OSCC is currently performed by applying the optimal contact concentrations for stomach cancer. In the present study, squamous carcinoma cell lines from human oral cancer were used to investigate the optimal contact concentrations of cisplatin (CDDP) and fluorouracil (5-FU) during CD-DST for OSCC. CD-DST was performed in 7 squamous cell carcinoma cell lines derived from human oral cancers (Ca9-22, HSC-3, HSC-4, HO-1-N-1, KON, OSC-19 and SAS) using CDDP $(0.15,0.3,1.25,2.5,5.0$ and $10.0 \mu \mathrm{g} / \mathrm{ml})$ and 5 -FU $(0.4,0.9$, $1.8,3.8,7.5,15.0$ and $30.0 \mu \mathrm{g} / \mathrm{ml})$, and the optimal contact concentrations were calculated from the clinical response rate of OSCC to single-drug treatment and the in vitro efficacy rate curve. The optimal concentrations were $0.5 \mu \mathrm{g} / \mathrm{ml}$ for CDDP and $0.7 \mu \mathrm{g} / \mathrm{ml}$ for 5-FU. The antitumor efficacy of CDDP at this optimal contact concentration in CD-DST was compared to the antitumor efficacy in the nude mouse method. The $\mathrm{T} / \mathrm{C}$ values, which were calculated as the ratio of the colony
\end{abstract}

Correspondence to: Dr Kaname Sakuma, Department of Oral and Maxillofacial Surgery, The Nippon Dental University School of Life Dentistry at Niigata, 1-8 Hamaura, Niigata, Niigata 951-8580, Japan E-mail: sakuma.k@ngt.ndu.ac.jp

Key words: anticancer drug sensitivity test, collagen gel droplet embedded culture drug sensitivity test, optimal contact concentration, anticancer drug resistance volume of the treatment group and the colony volume of the control group, at the optimal contact concentration of CDDP and of the nude mouse method were almost in agreement $(\mathrm{P}<0.05)$ and predicted clinical efficacy, indicating that the calculated optimal contact concentration is valid. Therefore, chemotherapy for OSCC based on anticancer drug sensitivity tests offers patients a greater freedom of choice and is likely to assume a greater importance in the selection of treatment from the perspectives of function preservation and quality of life, as well as representing a treatment option for unresectable, intractable or recurrent cases.

\section{Introduction}

Recent therapies for oral cancer have improved the curability of oral cancer and the 5-year survival rate of patients. This is a result of multidisciplinary therapy, in which wide resection and immediate reconstructive surgery brought about by advances in reconstructive surgery are combined with chemotherapy and radiation therapy (1-3). In addition, various therapies, including intra-arterial chemotherapy, that aim to preserve oral function through minimal invasion have been investigated to address the postoperative functional deterioration that accompanies surgical therapy (4). Additional therapies are being used with chemotherapy to reduce adverse effects by obtaining precise antitumor efficacy with minimum doses. These include multidrug therapy (docetaxel with cisplatin and fluorouracil) in preference to single-drug therapy (cisplatin), as well as superselective intra-arterial chemotherapy $(5,6)$. Drug resistance has also been investigated (7). Therefore, the clinical application of sensitivity tests for anticancer drugs is highly desirable to ensure that drugs are used effectively and appropriately. Prediction of the anticancer drug sensitivity of a particular tumor when chemotherapy is used not only contributes to improving patient outcome, but also prevents ineffective drug administration, thus reducing unnecessary physical and financial burdens (8-11).

In vivo anticancer drug sensitivity tests that have been developed at present include the nude mouse method and 
subrenal capsule assay method, and the clinical application of these methods has been investigated $(12,13)$. There is also considerable interest in in vitro methods, which, compared with in vivo methods, are easier to perform, less expensive and generate results within a shorter time. In 1995, Kobayashi et al (14) developed the collagen gel droplet-embedded culture drug sensitivity test (CD-DST), which combines the collagen gel droplet culture method, which is a simple method of three-dimensional (3D) culture that allows extremely small clinical samples to be tested, with a serum-free medium step and quantitative evaluation by image analysis. CD-DST has little effect on non-cancerous cells, allowing accurate measurements of cancerous cells only (14-16). This method has been used chiefly on tumors of the digestive system $(17,18)$. Compared to such cancers of the primary organs, oral squamous cell carcinoma (OSCC) and other oral cancers generally have a smaller tumor volume. CD-DST is therefore likely to be a suitable method for testing the sensitivity of anticancer drugs on OSCC, as this test can be used with a small volume of tumor tissue (14-16). However, since anticancer drug contact concentrations for OSCC have yet to be established by CD-DST; currently, OSCC is treated using drug contact concentrations established for the treatment of stomach cancer (19). Therefore, a basic investigation of the optimal contact concentration of cisplatin (CDDP) and fluorouracil (5-FU) was conducted using 7 squamous carcinoma cell lines derived from human oral cancers to establish the anticancer drug sensitivity for OSCC using CD-DST.

\section{Materials and methods}

Materials. The Ethics Committee of The Nippon Dental University School of Life Dentistry at Niigata (approval no., ECNG-H-119; Niigata, Japan) approved the present study. In total, 7 squamous cell carcinoma cell lines derived from human oral cancers were used, as follows: squamous cell carcinoma of the tongue, SAS, HSC-3, HSC-4 and OSC-19; squamous cell carcinoma of the gingiva, $\mathrm{Ca} 9-22$; squamous cell carcinoma of the buccal mucosa, HO-1-N-1; and squamous cell carcinoma of the floor of the mouth, KON. The SAS and Ca9-22 cell lines were purchased from the Health Science Research Resources Bank (National Institutes of Biomedical Innovation, Health and Nutrition, Osaka, Japan), and the HSC-3, HSC-4, HO-1-N-1, KON and OSC-19 cell lines were purchased from the Japanese Collection of Research Bioresources (National Institutes of Biomedical Innovation, Health and Nutrition). The cell lines were subcultured until use in Dulbecco's modified Eagle's medium (DMEM/F12; Nihon Pharmaceutical Co., Ltd., Tokyo, Japan) supplemented with $15 \%$ fetal bovine serum (FBS; Life Technologies; Thermo Fisher Scientific, Inc., Waltham, MA, USA), 0.1\% dispensable amino acid solution (Life Technologies; Thermo Fisher Scientific, Inc.), $50 \mathrm{U} / \mathrm{ml}$ penicillin, $50 \mu \mathrm{g} / \mathrm{ml}$ streptomycin (Life Technologies; Thermo Fisher Scientific, Inc.), and $0.25 \mu \mathrm{g} / \mathrm{ml}$ fungizone (Life Technologies; Thermo Fisher Scientific, Inc.). The subcultures were multilayered under conditions of $37^{\circ} \mathrm{C}$, $95 \%$ air and $5 \% \mathrm{CO}_{2}$ for $72 \mathrm{~h}$. During culture, cells were observed using an inverted-phase contrast microscope (Olympus, Tokyo, Japan). The anticancer drugs used in this study were CDDP (Bristol-Myers Squibb, Tokyo, Japan) and
5-FU (Kyowa Hakko Kirin, Tokyo, Japan). The 8 experimental animals were female nude BALB/c nu/nu mice aged 5-7 weeks (CLEA Japan, Inc., Tokyo, Japan).

Investigation of the specificity of anticancer drug sensitivity by reverse transcription-polymerase chain reaction ( $R T-P C R)$. Total RNA was extracted from the Ca9-22, HSC-3, HSC-4, HO-1-N-1, KON, OSC-19 and SAS cell lines seeded onto Petri dishes using the RNeasy Mini kit ${ }^{\circledR}$ (Qiagen, Hilden, Germany), according to the manufacturer's protocol. Using $1 \mu \mathrm{g}$ of total RNA, cDNA was synthesized using the High Capacity cDNA Reverse Transcription kit (Life Technologies; Thermo Fisher Scientific, Inc.). PCR amplification was performed using Platinum PCR Super Mix (Life Technologies; Thermo Fisher Scientific, Inc.) with the following gene-specific primers: Multidrug resistance gene 1 (MDR1) (20); multidrug resistance associated protein gene 1 (MRP1) (20); MRP2 (20); excision repair cross-complementing factor 1 (ERCC1) $(21,22)$; thymidine synthase (23); dihydropyrimidine dehydrogenase (DPD) (23); thymidine phosphorylase (TP) (23); and orotate phosphoribosyltransferase (OPRT) (23) (Table I). The PCR cycle consisted of the following conditions: Denaturation at $94^{\circ} \mathrm{C}$ for $15 \mathrm{sec}$; annealing at $55^{\circ} \mathrm{C}$ for $15 \mathrm{sec}$; and extension at $72^{\circ} \mathrm{C}$ for $60 \mathrm{sec}$. The cycle was repeated 35 times (Table I). The tests were conducted using the Applied Biosystems ${ }^{\circledR} 2720$ Thermal Cycler (Applied Biosystems; Thermo Fisher Scientific, Inc.). The internal control was glyceraldehyde-3-phosphate dehydrogenase, with PCR amplification performed under the same conditions. Electrophoresis was performed on a $2 \%$ agarose gel (Nippon Gene, Co., Ltd., Tokyo, Japan), and the PCR products were visualized by ethidium bromide staining for identification of the bands.

Sensitivity tests and anticancer drug concentrations. CD-DST was performed according to the method described by Kobayashi et al (14-16), using the Primaster ${ }^{\circledR}$ human cancer cell primary culture kit (Kurabo Industries Ltd., Osaka, Japan). The protocol was performed three times for each cell line (Fig. 1). Solution A (Cellmatrix ${ }^{\circledR}$ Type CD), solution $\mathrm{B}$ (F-12 medium at 10-fold concentration), and solution $\mathrm{C}$ (reconstitution buffer containing $50 \mathrm{mM} \mathrm{NaOH}, 260 \mathrm{mM}$ $\mathrm{NaHCO}_{3}$, and $200 \mathrm{mM} \mathrm{HEPES}$ ), which were included in the collagen gel culture kit, were mixed at a ratio of $8: 1: 1$ by volume to homogeneity to make a collagen solution. Each cell line was mixed with this collagen solution to $1-5 \times 10^{5}$ cells $/ \mathrm{ml}$, and the suspension was transferred into a 6-well multiplate (FALCON $\left.{ }^{\circledR}, \mathrm{NY}, \mathrm{USA}\right)$ using a micropipette in three $30-\mu 1$ droplets, making a total volume of $90 \mu \mathrm{l}$ per well $(15,16)$. In addition, three $30-\mu 1$ droplets were transferred onto a $40-\mathrm{mm}$ dish as a reference to determine the growth rate. Subsequent to gelation in a $\mathrm{CO}_{2}$ incubator at $37^{\circ} \mathrm{C}$ for $1 \mathrm{~h}$, the droplets in each well were overlaid with DMEM/F12 containing $10 \%$ FBS and cultured for $24 \mathrm{~h}$. Drug contact was thus performed under conditions approximating physiological conditions. The maximum concentration was twice the maximum blood concentration during clinical administration, and the minimum concentration was the steady state concentration. CDDP was added at concentrations of $0.15,0.3,1.25,2.5$, 5.0 and $10.0 \mu \mathrm{g} / \mathrm{ml}$. 5-FU was added at concentrations of 0.4 , 


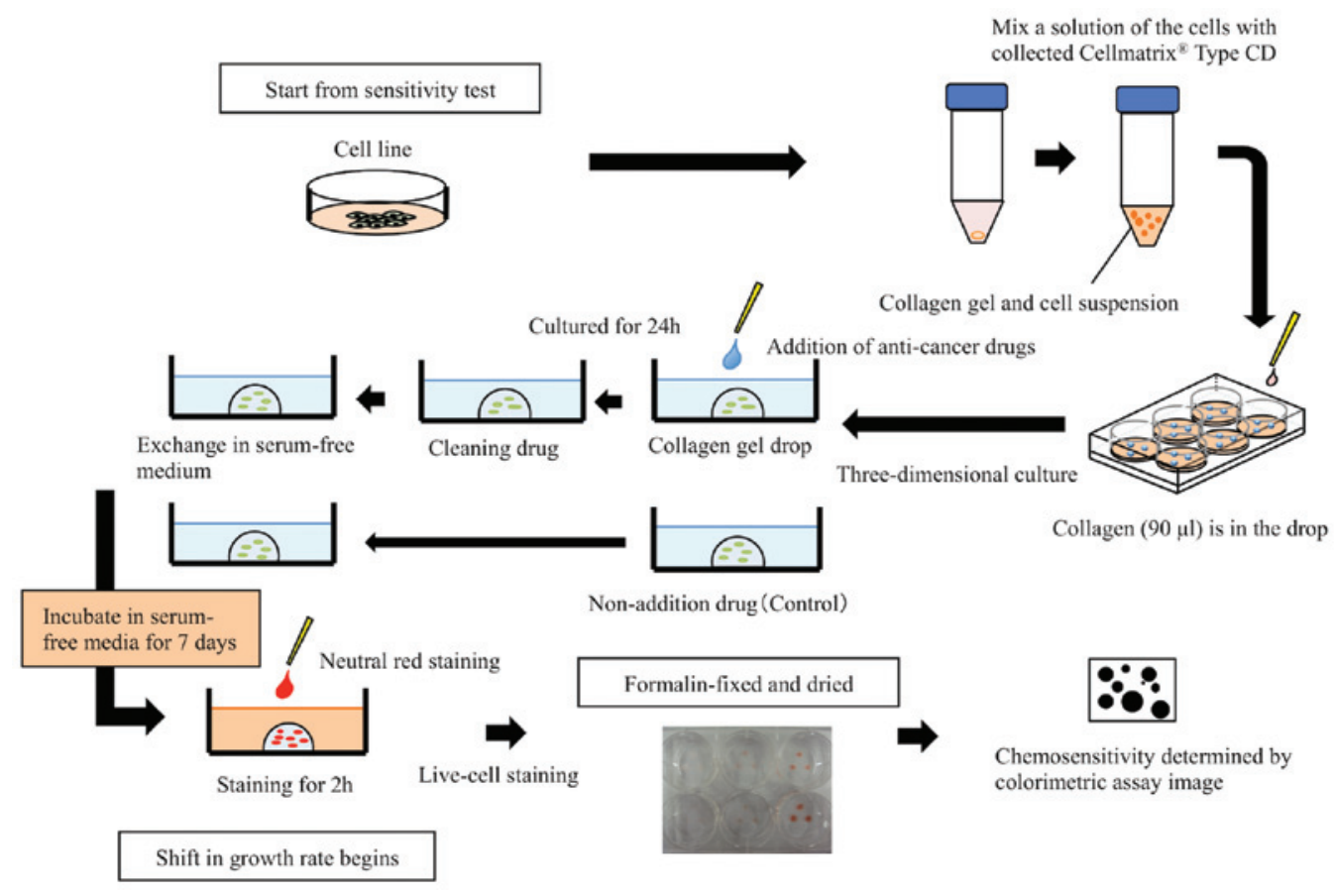

Figure 1. Overview of the collagen gel droplet-embedded culture drug sensitivity test method.

$0.9,1.8,3.8,7.5,15.0$ and $30.0 \mu \mathrm{g} / \mathrm{ml}$, and the droplets were returned to the $\mathrm{CO}_{2}$ incubator and left in contact with the drug for $24 \mathrm{~h}$. Following contact, the culture medium in each well was removed by suction, and the droplets were washed twice with phosphate-buffered saline (PBS; Takara Bio Inc., Otsu, Japan) to remove the anticancer drug. The cells were then growth-cultured for 7 days in serum-free medium. At this time, to compare the cell growth rate, the reference plate was stained and fixed. Subsequent to cultivation for 7 days, neutral red solution (Kurabo Industries Ltd.) was added to each well, and the cells were incubated at $37^{\circ} \mathrm{C}$ for another $2 \mathrm{~h}$. The cells were fixed by replacing the solution with $10 \%$ neutral formalin (Wako Pure Chemical Industries Ltd., Osaka, Japan) for $40 \mathrm{~min}$. The culture plates were then washed three times in PBS and air-dried for $10 \mathrm{~h}$. Drug efficacy was determined by image analysis (Solution Systems Inc., Chiba, Japan).

Determination of efficacy by image analysis. Antitumor efficacy was determined according to the method of Koezuka et al (24) using the Primage ${ }^{\circledR}$ image analysis device (Kurabo Industries Ltd.). Imaging of the plate samples obtained from the sensitivity tests was performed by acquiring grayscale images using the image analysis device. Images other than those of the cancer cells that were unnecessary for the analysis were separated and removed from the sample images using a shade (density gradation demarcation) or shape (grain shape separation) extraction function. Cancer cell growth and antitumor efficacy were determined by measuring the volume of the colony from the cancer cell images. The treatment group, which was in contact with the anticancer drug, and the control group, which was not in contact with the drug, were compared by calculating the ratio of the colony volume of the treatment group $\left(\mathrm{V}_{\mathrm{T}}\right)$ and the colony volume of the control group $\left(\mathrm{V}_{\mathrm{C}}\right)\left(\mathrm{V}_{\mathrm{T}} / \mathrm{V}_{\mathrm{C}}\right)$. This ratio was the T/C value; a T/C value $\leq 50 \%$ indicated high sensitivity and a T/C value $>50 \%$ indicated low sensitivity. The standard for an evaluable colony was a tumor cell growth rate at the time of image analysis processing of $\geq 0.8$ times the rate at the start of the experiment.

Calculation of optimal contact concentration. The optimal contact concentrations of CDDP and 5-FU were established using the method described by Nagai et al (25). Using the $\mathrm{T} / \mathrm{C}$ values obtained from the anticancer drug sensitivity tests for the 7 cell lines, an efficacy ratio curve was plotted with the cumulative efficacy rate $(\%)$ on the vertical axis against anticancer drug concentration $(\mu \mathrm{g} / \mathrm{ml})$ on the horizontal axis. From this, the logarithmic trendline $y=a \cdot \ln (x)+b$ was calculated. Using the already-known clinical response rates of oral cancer to single-drug treatment with the two anticancer drugs [CDDP, $26.3 \%$ (26); 5-FU, $13.0 \%$ (27)] on the $\mathrm{Y}$-axis, the optimal contact concentration could then be read off along the $\mathrm{X}$-axis.

Antitumor efficacy of CDDP in cancer-bearing nude mice. The nude mouse method was used to investigate whether the CD-DST results of the calculated optimal contact concentration was associated with those of the 7 cell lines. Cells $\left(0.3 \mathrm{ml}\right.$ of a suspension of $1 \times 10^{7}$ cells $/ \mathrm{ml}$ of Hanks' solution) from 6 cell lines (excluding KON) were transferred to nude mice under the flank skin. When the size of the tumor was $100-300 \mathrm{~mm}^{3}$ [tumor size $=0.5 \mathrm{x}$ (longest diameter $\mathrm{x}$ shortest diameter $\left.{ }^{2}\right)$, the experiment was commenced. The dose of the anticancer drug was the clinically equivalent dose (CED) reported by Inaba et al $(28,29)$. This is the dose at which the peripheral concentration of the anticancer drug in nude mouse experimental models was the same as the peripheral concentration in human patients treated with an effective dose. On the basis of CED, $7.0 \mathrm{mg} / \mathrm{kg}$ CDDP was 


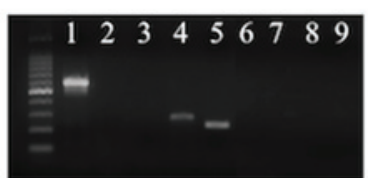

Ca9-22

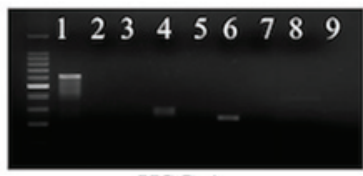

HSC-4

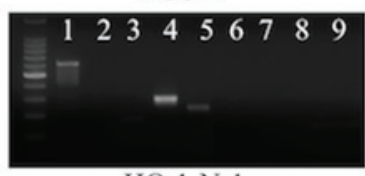

$\mathrm{HO}-1-\mathrm{N}-1$

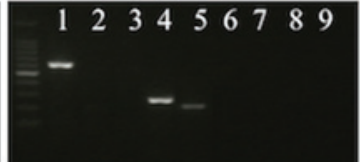

SAS

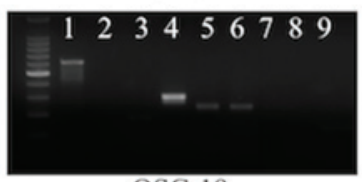

OSC-19

$1: \mathrm{GAPDH}$

2:MDR1

3:MRP2

4:OPRT

5:MRP1

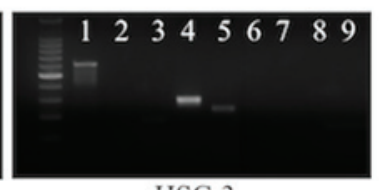

HSC-3

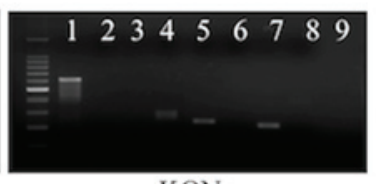

6:DPD

7:TS

8:TP

9:ERCC1

Figure 2. Results of reverse transcription-polymerase chain reaction amplification. ERCC1 was not expressed in any of the cell lines, while expression of OPRT was found in all cell lines. No clear specificity in the expression of resistance genes or enzymes associated with metabolism was observed in the 7 cell lines. GAPDH, glyceraldehyde 3-phosphate dehydrogenase; MDR1, multidrug resistance gene 1; MRP2, multidrug resistance associated protein gene 2; OPRT, orotate phosphoribosyltransferase; TS, thymidine synthase; TP, thymidine phosphorylase; MRP1, multidrug resistance associated protein gene 1; DPD, dihydropyrimidine dehydrogenase; ERCC1,. excision repair cross-complementing factor 1.

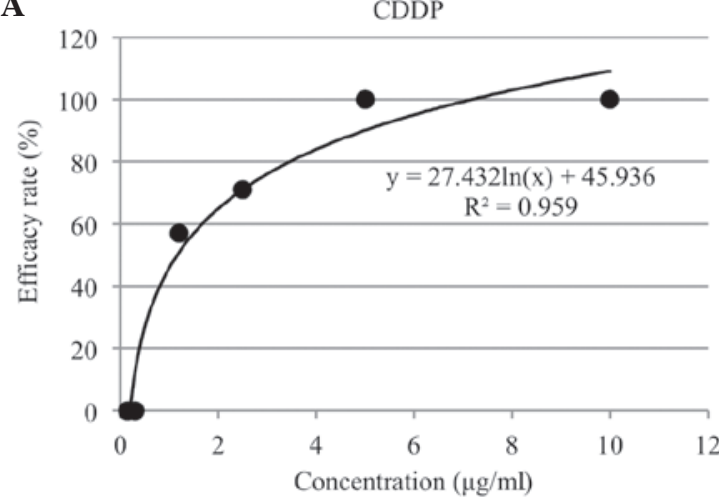

B

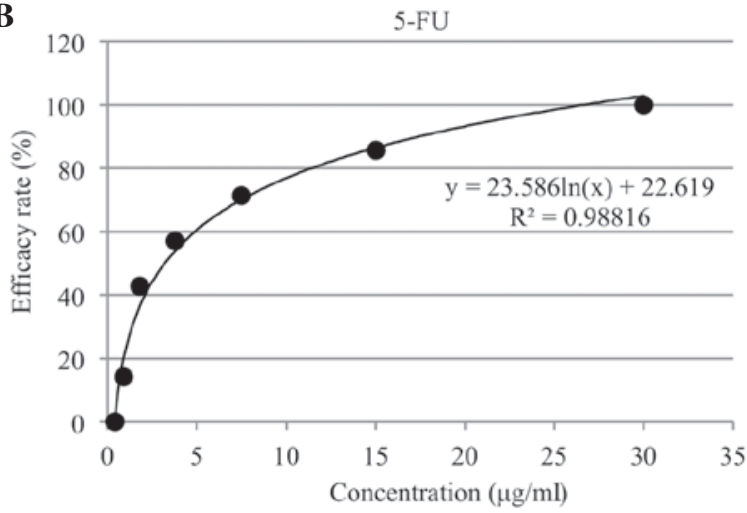

Figure 3. Cumulative efficacy rate curves for (A) CDDP and (B) 5-FU. The cumulative efficacy rate curve is shown with the cumulative efficacy rate (\%) on the Y-axis plotted against the anticancer drug concentration $(\mu \mathrm{g} / \mathrm{ml})$ on the $\mathrm{X}$-axis. The logarithmic trendline $\mathrm{y}=\mathrm{a} . \mathrm{ln}(\mathrm{x})+\mathrm{b}$ was determined and plotted. Using the known clinical response rates of oral cancer to single-drug treatment with the two anticancer drugs (CDDP, 26.3\%; 5-FU, 13.0\%) on the Y-axis, the optimal contact concentration could be extrapolated from the X-axis. CDDP, cisplatin; 5-FU, fluorouracil.

administered as a single intravenous injection to the tail vein to reproduce the antitumor efficacy of clinical administration in humans $(28,29)$. The antitumor efficacy of the anticancer drug was determined by calculating the T/C value at 21 days post-administration from the relative tumor weight of the drug treatment group and the control group, according to the method described by Geran et al (30). A T/C value $\leq 50 \%$ indicated high sensitivity and a $\mathrm{T} / \mathrm{C}$ value $>50 \%$ indicated low sensitivity. The calculated $\mathrm{T} / \mathrm{C}$ values were compared to those from the CD-DST model for each cell line. All procedures were performed to minimize pain and discomfort according to the Guidelines for the Care and Use of Laboratory Animals, The Nippon Dental University School of Life Dentistry at Niigata (approval no., 131).

Statistical analysis. All statistical analyses were performed using the SPSS version 13.0J statistical software (SPSS, Inc., Chicago, IL, USA). The Mann-Whitney U test and Pearson's correlation coefficient were used for comparisons among groups. $\mathrm{P}<0.05$ was considered to indicate a statistically significant difference.

\section{Results}

Specificity of anticancer drug sensitivity of the 7 cell lines. ERCC1 was not expressed in any of the cell lines, whereas OPRT was expressed in all cell lines. No clear specificity in the expression of resistance genes or enzymes associated with metabolism was detected (Fig. 2).

Sensitivity of the 7 cell lines to CDDP and 5-FU at each contact concentration. The results of CD-DST using the 7 cell lines are shown in Table II. The contact concentrations at which all cell lines showed low sensitivity were $\leq 0.3 \mu \mathrm{g} / \mathrm{ml}$ for CDDP and $0.4 \mu \mathrm{g} / \mathrm{ml}$ for 5-FU. Calculation of the cumulative efficacy rate of the 7 cell lines at each contact concentration showed that the efficacy rate at $1.25 \mu \mathrm{g} / \mathrm{ml}$ CDDP was $57.1 \%$ and at $0.9 \mu \mathrm{g} / \mathrm{ml} 5$-FU was $14.2 \%$. 
Table I. Sequence of polymerase chain reaction primers.

Annealing

Gene

Forward primer, 5'-3'

Reverse primer, 5'-3' temperature, ${ }^{\circ} \mathrm{C}$

\begin{tabular}{llll}
\hline MDR1 & CAGTGTTTGCCATAGTATTTTCAAGGATTG & CCCTTTAACACTAGAAGCATCAC & 42 \\
MRP1 & CGGAAACCATCCACGACCCTAATCC & ACCTCCTCATTCGCATCCACCTTGG & 42 \\
MRP2 & CTGCCTCTTCAGAATCTTAG & CCCAAGTTGCAGGCTGGCC & 55 \\
ERCC1 & GGGAATTTGGCGACGTAATTC & GCGGAGGCTGAGGAACGA & 55 \\
DPD & TGTTCGGACAGAGCAAGATG & CTTCAATCCGGCCATTTCTA & 55 \\
OPRT & ACGCCGGGGCGCCTGGGAGTTTGA & TTTCCAGCCAGTGACTTTCAGGAGGAC & 55 \\
TS & ACCAACCCTGACGACAGAAG & ATGCGGATTGTACCCTTCAA & 55 \\
TP & AGGAGACCTCGGTGCTGAC & TGAGAATGGAGGCTGTGATG & 55 \\
GAPDH & GTCAAGGCTGAGAACGGGAA & GCTTCACCACCTTCTTGATG & 55
\end{tabular}

MDR1, multidrug resistance gene 1; MRP1, multidrug resistance associated protein gene 1; MRP2, multidrug resistance associated protein gene 2; ERCC1, excision repair cross-complementing factor 1; DPD, dihydropyrimidine dehydrogenase; OPRT, orotate phosphoribosyltransferase; TS, thymidine synthase; TP, thymidine phosphorylase; GAPDH, glyceraldehyde-3-phosphate dehydrogenase.
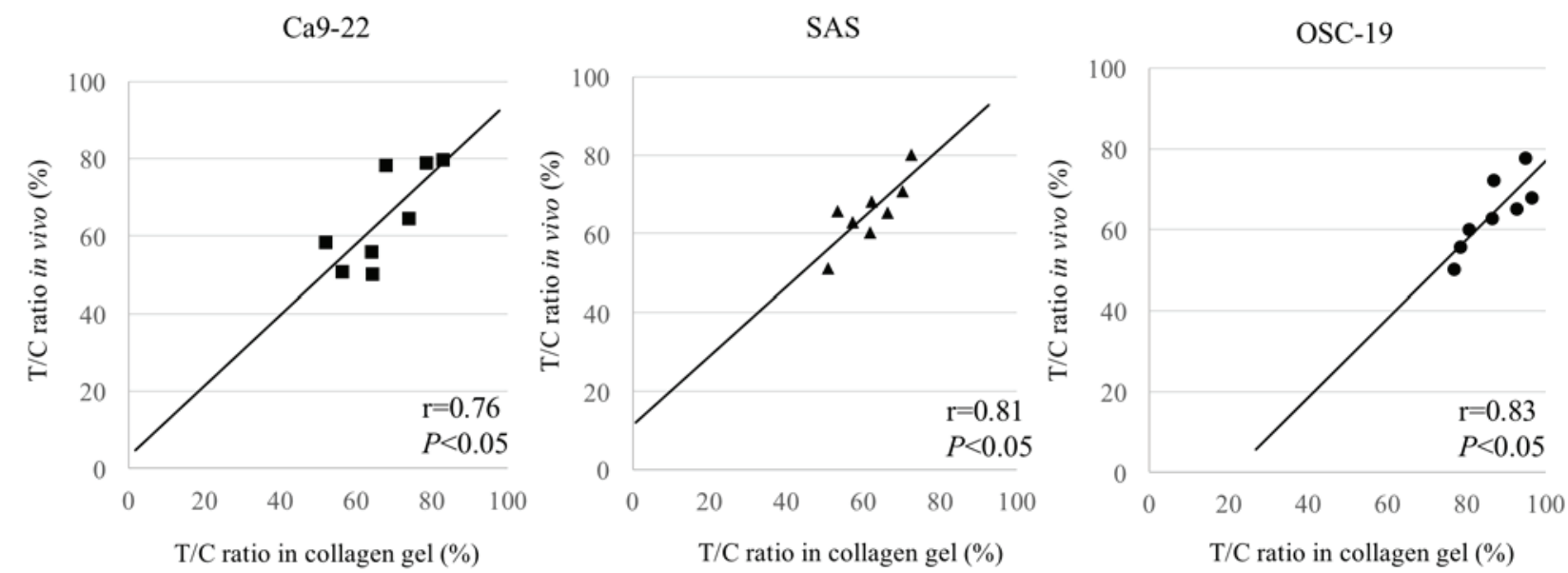

Figure 4. Association between the antitumor effect in nude mice and the CD-DST $(\mathrm{n}=8)$. The graph is a comparison of the T/C value, which was calculated as the ratio of the colony volume of the treatment group and the colony volume of the control group, obtained from administering CDDP to nude mice at clinically equivalent dose and the T/C value obtained from CD-DST with CDDP at the optimal contact concentration $(0.5 \mu \mathrm{g} / \mathrm{ml})$. CDDP, cisplatin; CD-DST, collagen gel droplet-embedded culture drug sensitivity test.

Calculation of the optimal contact concentrations of CDDP and 5-FU. The in vitro cumulative efficacy rate curves of the cumulative efficacy rate (\%) against the contact concentration $(\mu \mathrm{g} / \mathrm{ml})$ for CDDP and 5-FU are shown in Fig. 3A and B. The optimal contact concentrations, determined by reading off the concentrations for the known clinical response rates of the single-drug treatment on the logarithmic trendline, were $0.5 \mu \mathrm{g} / \mathrm{ml}$ for CDDP and $0.7 \mu \mathrm{g} / \mathrm{ml}$ for $5-\mathrm{FU}$.

Comparison of CD-DST and nude mouse results for CDDP. Of the 6 cell lines used (excluding KON), engraftment was confirmed in the SAS, Ca9-22 and OSC-19 cell lines. The results of treating nude tumor-bearing mice with CDDP at the CED were compared with the CD-DST results for the same cell lines of CDDP administered at the optimal contact concentration $(0.5 \mu \mathrm{g} / \mathrm{ml})$. The T/C values from CD-DST were as follows: Ca9-22, 67.3\%; SAS, 61.7\%; and OSC-19, $86.6 \%$. The $\mathrm{T} / \mathrm{C}$ values from the nude mouse CED method were as follows: $\mathrm{Ca} 9-22,64.6 \%$; SAS, 65.6\%; and OSC-19, $64.0 \%(\mathrm{P}<0.05)$. The $\mathrm{T} / \mathrm{C}$ values obtained from the two different methods were therefore almost equal (Fig. 4).

\section{Discussion}

In previous years, there have been studies of anticancer drug sensitivity tests used for the selection of appropriate anticancer drugs for individual tumors $(18,31,32)$. The nude mouse grafting method for testing drug sensitivity was reported in 1969 (12), and since then, SRC methods have been developed (13). However, these drug sensitivity tests were not well suited for clinical use, due to their low success rate and high costs, and the time required for the results to be obtained. In vitro tests, such as human tumor colony assay and succinate dehydrogenase inhibition, were subsequently announced, although there were challenges with the success rate of the primary culture and drug contact concentration $(33,34)$. The 
Table II. Results of the CD-DST method in the SAS, Ca9-22, HSC-3, HO-1-N-1, HSC-4, KON and OSC-19 cell lines. $\mathrm{A}, \mathrm{CDDP}$

\begin{tabular}{|c|c|c|c|c|c|c|c|c|c|}
\hline \multirow[b]{2}{*}{ Cells,$\mu \mathrm{g} / \mathrm{ml}$} & \multicolumn{7}{|c|}{ Cell line } & \multicolumn{2}{|c|}{ Cumulative efficacy } \\
\hline & SAS & Ca9-22 & HSC-3 & HO-1-N-1 & HSC-4 & $\mathrm{KON}$ & OSC-19 & Cell lines, $\mathrm{n}$ & Rate, $\%$ \\
\hline 0.15 & 92.1 & 112.9 & 107.1 & 97.9 & 101.4 & 90.3 & 108.9 & $0 / 7$ & 0.0 \\
\hline 0.30 & 91.4 & 87.5 & 98.3 & 90.5 & 86.1 & 88.9 & 90.7 & $0 / 7$ & 0.0 \\
\hline 1.25 & 38.1 & 35.5 & 88.2 & 72.9 & 43.1 & 45.1 & 79.7 & $4 / 7$ & 57.1 \\
\hline 2.50 & 9.6 & 8.2 & 65.6 & 28.2 & 21.9 & 22.9 & 67.7 & $5 / 7$ & 71.4 \\
\hline 5.00 & 3.8 & 6.9 & 35.3 & 4.9 & 9.2 & 8.3 & 44.4 & $7 / 7$ & 100.0 \\
\hline 10.00 & 2.2 & 3.4 & 8.5 & 1.4 & 2.3 & 6.2 & 36.0 & $7 / 7$ & 100.0 \\
\hline
\end{tabular}

$\mathrm{B}, 5-\mathrm{FU}$

\begin{tabular}{|c|c|c|c|c|c|c|c|c|c|}
\hline \multirow[b]{2}{*}{ Cells, $\mu \mathrm{g} / \mathrm{ml}$} & \multicolumn{7}{|c|}{ Cell line } & \multicolumn{2}{|c|}{ Cumulative efficacy } \\
\hline & SAS & Ca9-22 & HSC-3 & HO-1-N-1 & HSC-4 & $\mathrm{KON}$ & OSC-19 & Cell lines, $\mathrm{n}$ & Rate, $\%$ \\
\hline 0.4 & 110.0 & 50.1 & 86.8 & 87.0 & 77.5 & 75.6 & 81.6 & $0 / 7$ & 0.0 \\
\hline 0.9 & 88.2 & 23.8 & 55.1 & 86.3 & 63.3 & 50.4 & 76.6 & $1 / 7$ & 14.2 \\
\hline 1.8 & 34.3 & 18.5 & 53.8 & 73.7 & 62.6 & 40.5 & 76.0 & $3 / 7$ & 42.8 \\
\hline 3.8 & 13.1 & 4.5 & 52.2 & 59.6 & 28.9 & 20.1 & 71.7 & $4 / 7$ & 57.1 \\
\hline 7.5 & 6.9 & 4.3 & 51.4 & 48.9 & 29.9 & 12.2 & 60.4 & $5 / 7$ & 71.4 \\
\hline 15.0 & 3.7 & 3.4 & 43.0 & 21.6 & 20.4 & 6.2 & 59.2 & $6 / 7$ & 85.7 \\
\hline 30.0 & 3.3 & 3.3 & 30.3 & 4.6 & 10.6 & 6.9 & 44.8 & $7 / 7$ & 100.0 \\
\hline
\end{tabular}

The contact concentrations at which all cell lines show low sensitivity are $\leq 0.3 \mu \mathrm{g} / \mathrm{ml}$ for CDDP and $0.4 \mu \mathrm{g} / \mathrm{ml}$ for 5-FU. The cumulative efficacy rate for the 7 cell lines at each contact concentration was calculated. At $1.25 \mu \mathrm{g} / \mathrm{ml}$ of CDDP, the rate is $57.1 \%$, and at $0.9 \mu \mathrm{g} / \mathrm{ml}$ of 5 -FU, the rate is $14.2 \%$. CDDP, cisplatin; 5-FU, fluorouracil.

CD-DST method, which was developed in 1995, is an in vitro method of testing anticancer drug sensitivity that combines the 3D culture of isolated cells embedded in collagen gel droplets and image colorimetry (14). The particular features of this method are that it allows testing using smaller quantities of cells compared with conventional assays, eliminates the effects of fibroblasts that may adulterate samples at the time of harvesting, and allows the evaluation of physiological drug concentrations $(14,15)$. Therefore, CD-DST is a useful method for predicting efficacy prior to the administration of an anticancer drug. Measurement success rates of $\geq 80 \%$ have been obtained for cancers, including colorectal cancer (18), lung cancer (31) and breast cancer (32), and a high clinical efficacy prediction rate of $91 \%$ has been obtained (35). The CD-DST method is therefore expected to have future application as an anticancer drug sensitivity test in fundamental research and clinical practice involving OSCC. However, at present, optimal anticancer drug contact concentrations have not been established using the CD-DST method for OSCC; instead, tests are performed using the contact concentrations for stomach cancer (adenocarcinoma) (36). Sensitivity has been clearly shown to differ according to the organ or tissue type; therefore, there is a possibility of erroneous evaluation of the antitumor efficacy of anticancer drugs for OSCC $(18,31,32)$. Establishing the optimal contact concentrations of anticancer drugs for OSCC is therefore warranted.

In the present study, cell lines were used instead of clinical specimens to establish optimal contact concentrations. First, the specificity of each cell line was examined using RT-PCR. No clear specificity in the expression of resistance genes or enzymes associated with metabolism was observed in the 7 cell lines. No ERCC1 expression was detected in the 7 cell lines. ERCC1 is a protein involved in nucleotide excision repair of DNA, and it affects CDDP resistance $(37,38)$. It also enhances DNA repair capacity by acting as a rate-limiting enzyme that removes CDDP-DNA compounds in the nucleotide cleavage and modification pathway (39). The group that did not express ERCC1 may be expected to exhibit a greater effect of CDDP than the group that exhibited ERCC1; therefore, ERCC1 has increasingly broad implications as a prognostic factor in CDDP-based chemotherapy (40). By contrast, OPRT was expressed in all cell lines. OPRT is considered to be involved in DNA synthesis inhibition as well as RNA dysfunction by converting 5-FU to 5-fluorouridinemonophosphate (41). Although it was previously reported that the sensitivity of 5-FU could be predicted from OPRT enzyme activity (42), it has also been reported that there is no correlation between OPRT expression and antitumor efficacy $(43,44)$. Watanabe et al (45) reported that a metabolic pathway mediated by 
OPRT is central to drug efficacy expression in OSCC, and that a high expression of OPRT is essential for drug sensitivity. The present study showed that the 7 cell lines possessed no clear indication of drug resistance and no specificity in their drug sensitivity, thus prompting their use in the present study.

First, the sensitivities of the 7 OSCC cell lines toward CDDP and 5-FU were investigated at different contact concentrations using the CD-DST method. The optimal contact concentration of CDDP was $0.3 \mu \mathrm{g} / \mathrm{ml}$, which is higher than that for stomach cancer $(0.2 \mu \mathrm{g} / \mathrm{ml})$, and all cell lines showed low sensitivity. It therefore appears that the optimal contact concentration of CDDP for OSCC treatment is increased compared with the optimal contact concentration for stomach cancer. With 5-FU, all cell lines showed low sensitivity at $0.4 \mu \mathrm{g} / \mathrm{ml}$, which is lower than the optimal contact concentration for stomach cancer $(1.0 \mu \mathrm{g} / \mathrm{ml})$. At $0.9 \mu \mathrm{g} / \mathrm{ml}, 1$ of the 7 cell lines (Ca9-22 cells) showed high sensitivity, and the cumulative efficacy rate was $14.2 \%$. Taking into consideration that the clinical response rate obtained by single-drug treatment with 5-FU was $13.0 \%$, it could be deduced that the optimal contact concentration of 5-FU is likely be lower for OSCC than for stomach cancer.

The optimal contact concentrations of CDDP and 5-FU for OSCC were calculated from the CD-DST of the 7 cell lines, according to the method described by Nagai et al (25) and were compared with the contact concentrations currently used clinically for stomach cancer $(0.2 \mu \mathrm{g} / \mathrm{ml})(24)$. CDDP had an optimal contact concentration value of $0.5 \mu \mathrm{g} / \mathrm{ml}$, which was increased compared with that of stomach cancer $(0.2 \mu \mathrm{g} / \mathrm{ml})$, whereas 5-FU had an optimal contact concentration value of $0.7 \mu \mathrm{g} / \mathrm{ml}$, which was decreased compared with that of stomach cancer $(1.0 \mu \mathrm{g} / \mathrm{ml})$. Using CD-DST, Nagai et al (25) found the optimal contact concentration of CDDP to be $\sim 1.0 \mu \mathrm{g} / \mathrm{ml}$ for uterine body and cervical cancers and $2.0 \mu \mathrm{g} / \mathrm{ml}$ for ovarian cancer, which are all increased compared with the contact concentrations of stomach cancer $(0.2 \mu \mathrm{g} / \mathrm{ml})$. Thus, the sensitivity to an anticancer drug varies according to the organ or tissue type. In addition, the clinical response rate obtained by single-drug treatment with CDDP has been reported to be $57.8 \%$ for ovarian cancer (8), 39.4\% for cervical cancer (9), and $19.1 \%$ for stomach cancer (10). There is therefore a trend for the contact concentration to decrease at lower clinical response rates. The clinical response rate of CDDP for OSCC is $26.3 \%$ (26); therefore, on the basis of the aforementioned trend, the optimal contact concentration of $0.5 \mu \mathrm{g} / \mathrm{ml}$ appears valid.

An in vivo verification test was performed to examine the clinical efficacy of CDDP, in which nude mice were used as models of clinical efficacy in humans. The cell lines were transplanted into nude mice, and the tumor-bearing nude mice were administered a single dose of CDDP by injection into the tail vein with the CED of $7.0 \mathrm{mg} \mathrm{kg}$ established by Inaba et al (29) in order to reproduce the antitumor efficacy of anticancer drugs in humans. This method was used to predict the clinical antitumor efficacy. The in vitro antitumor efficacy is generally determined by the concentration of the drug in culture and the time for which it acts. However, it is extremely challenging to reproduce changes in blood concentration at the clinical dose in mice. Using the CED in vivo facilitated the determination of the antitumor efficacy similar to when the drug is administered to humans $(26,27)$.
The present in vivo verification test was performed with the CED of CDDP, and the clinical effects appear to have been reproduced. The T/C value from CD-DST, with an optimal contact concentration of $0.5 \mu \mathrm{g} / \mathrm{ml}$, and the $\mathrm{T} / \mathrm{C}$ values from the CED nude mouse method were almost in agreement for the SAS, Ca9-22 and OSC-19 cell lines $(\mathrm{P}<0.05)$, indicating that CD-DST is likely to be predictive of clinical efficacy.

CD-DST combines the collagen gel droplet culture method, a simple 3D culture method that allows the analysis of extremely small clinical samples, with a serum-free medium step and quantitative evaluation by image analysis. Furthermore, CD-DST has little effect on non-cancerous cells, allowing accurate measurements of cancerous cells only. Thus, CD-DST is an ideal anticancer drug sensitivity test that overcomes the challenges of other sensitivity tests, and CD-DST is widely used in clinical practice for lung, breast and colorectal cancer $(18,31,32)$. In addition to OSCC, chemotherapy based on anticancer drug sensitivity tests offers patients increased freedom of choice. CD-DST is likely to be important in the selection of treatment, in terms of function preservation and quality of life, and also as a treatment option in unresectable, intractable or recurrent cases. However, the optimal contact concentrations determined in the present study are a basic stage for performing tests using clinical samples. Additional sensitivity tests performed on clinical samples are required, using the calculated optimal contact concentrations to evaluate reproducibility on the basis of clinical data.

\section{References}

1. Adelstein DJ, Li Y, Adams GL, Wagner H Jr, Kish JA, Ensley JF, Schuller DE and Forastiere AA: An intergroup phase III comparison of standard radiation therapy and two schedules of concurrent chemoradiotherapy in patients with unresectable squamous cell head and neck cancer. J Clin Oncol 21: 92-98, 2003.

2. Wendt TG, Grabenbauer GG, Rödel CM, Thiel HJ, Aydin H, Rohloff R, Wustrow TP, Iro H, Popella C and Schalhorn A: Simultaneous radiochemotherapy versus radiotherapy alone in advanced head and neck cancer: a randomized multicenter study. J Clin Oncol 16: 1318-1324, 1998.

3. Adelstein DJ, Lavertu P, Saxton JP, Secic M, Wood BG, Wanamaker JR, Eliachar I, Strome M and Larto MA: Mature results of a phase III randomized trial comparing concurrent chemoradiotherapy with radiation therapy alone in patients with stage III and IV squamous cell carcinoma of the head and neck. Cancer 88: 876-883, 2000.

4. Fuwa N, Ito Y, Matsumoto A, Kamata M, Kodaira T, Furutani K, Sasaoka M, Kimura Y and Morita K: A combination therapy of continuous superselective intraarterial carboplatin infusion and radiation therapy for locally advanced head and neck carcinoma. Phase I study. Cancer 89: 2099-2105, 2000.

5. Posner MR, Hershock DM, Blajman CR, Mickiewicz E, Winquist E, Gorbounova V, Tjulandin S, Shin DM, Cullen K, Ervin TJ, Murphy BA, et al; TAX 324 Study Group: Cisplatin and fluorouracil alone or with docetaxel in head and neck cancer. N Engl J Med 357: 1705-1715, 2007.

6. Forastiere AA, Goepfert H, Maor M, Pajak TF, Weber R, Morrison W, Glisson B, Trotti A, Ridge JA, Chao C, et al: Concurrent chemotherapy and radiotherapy for organ preservation in advanced laryngeal cancer. N Engl J Med 349: 2091-2098, 2003.

7. Suzuki M, Ishikawa H, Tanaka A and Mataga I: Heterogeneity of anticancer drug sensitivity in squamous cell carcinoma of the tongue. Human Cell 24: 21-29, 2011.

8. Kato T: Phase II study of CIS-diamminedichloroplatinum (II) by collaborative study. Gan To Kagaku Ryoho 9: 694-701, 1982 (In Japanese). 
9. Noda K, Takeuchi S, Kurihara S, Sugawa T, Kato T, Ikeda M, Kanazawa K, Tsutsui F, Yamamoto K, Umezu J, et al: Phase II study of cisplatin in cervical and endometrial carcinomas. Gan To Kagaku Ryoho 14: 1129-1135, 1987 (In Japanese).

10. Ishibiki K, Kumai K, Kodaira S, Abe O, Yamamoto K, Oouchi T, Fukaya Y, Kimura K, Takamatsu K, Ootsuka E, et al: Phase II study with cisplatin in advanced stomach and colon carcinoma. Cooperative study group of cisplatin for stomach and colon carcinoma. Gan To Kagaku Ryoho 16: 3185-3193, 1989 (In Japanese).

11. Kondo T, Kubota T, Tanimura H, Yamaue H, Akiyama S, Maehara Y, Tanigawa N, Kitajima M and Takagi H: Cumulative results of chemosensitivity tests for antitumor agents in Japan. Japan Research Society for Appropriate Cancer Chemotherapy. Anticancer Res 20: 2389-2392, 2000.

12. Rygaard $\mathbf{J}$ and Povlsen CO: Heterotransplantation of a human malignant tumor to 'Nude' mice. Acta Pathol Microbiol Scand 77: 758-760, 1969.

13. Bogden AE, Cobb WR, Lepage DJ, Haskell PM, Gulkin TA Ward A, Kelton DE and Esber HJ: Chemotherapy responsiveness of human tumors as first transplant generation xenografts in the normal mouse: Six-day subrenal capsule assay. Cancer 48: 10-20, 1981.

14. Kobayashi H, Tanisaka K, Kondo N, Mito Y, Koezuka M, Yokouchi H, Higashiyama M, Kodama K, Doi O, Yamada M, et al: Development of new in vitro chemosensitivity test using collagen gel droplet embedded culture and its clinical usefulness. Gan To Kagaku Ryoho 22: 1933-1939, 1995 (In Japanese).

15. Kobayashi H, Higashiyama M, Minamigawa K, Tanisaka K, Takano T, Yokouchi H, Kodama K and Hata T: Examination of in vitro chemosensitivity test using collagen gel droplet culture method with colorimetric endpoint quantification. Jpn J Cancer Res 92: 203-210, 2001.

16. Kobayashi H: Development of a new in vitro chemosensitivity test using collagen gel droplet culture and image analysis for clinical usefulness. Recent Results Cancer Res 161: 48-61, 2003.

17. Hanatani Y, Kobayashi H, Kodaira S, Takami H, Asagoe T and Kaneshiro E: An in vitro chemosensitivity test for gastric cancer using collagen gel droplet embedded culture. Oncol Rep 7: $1027-1033,2000$.

18. Araki Y, lsomoto H, Matsumoto A, Kaibara A, Yasunaga M, Hayashi K, Yatsugi H and Yamauchi K: An in vitro chemosensitivity test for colorectal cancer using collagen-gel droplet embedded cultures. Kurume Med J 46: 163-166, 1999.

19. Shintani S, Hino S, Nakashiro K and Hamakawa H: Clinical trial of chemotherapy identified according to chemosensitivity assay for oral cancer patients with unresectable recurrent lesions. Gan To Kagaku Ryoho 33: 357-360, 2006 (In Japanese).

20. Matsumoto Y, Tamiya T and Nagano S: Resistance to topoisomerase II inhibitors in human glioma cell lines overexpressing multidrug resistant associated protein (MRP) 2. J Med Invest 52: 41-48, 2005.

21. Selvakumaram M, Pisarcik DA, Bao R, Yeung AT and Hamilton TC: Enhanced cisplatin cytotoxicity by disturbing the nucleotide excision repair pathway in ovarian cancer cell lines. Cancer Res 63: 1311-1316, 2003.

22. Bartolucci R, Wei J, Senchez JJ, Perez-Roca L, Chaib I, Puma F, Farabi R, Mendez P, Roila F, Okamoto T, et al: XPG mRNA expression levels modulate prognosis in resected non-small-cell lung cancer in conjunction with BRCA1 and ERCC1 expression. Clin Lung Cancer 10: 47-52, 2009.

23. Park JS, Young Yoon S, Kim JM, Yeom YI, Kim YS and Kim NS: Identification of novel genes associated with the response to 5-FU treatment in gastric cancer cell lines using a cDNA microarray. Cancer Lett 214: 19-33, 2004

24. Koezuka M, Kondo N, Kobayashi H, Hara S, Yasutomi M, Nishida S, Hashimoto S and Asano H: Drug sensitivity test for human cancer-cells using collagen gel embedded culture and image analysis. Int J Oncol 2: 953-959, 1993.

25. Nagai N, Minamikawa K, Mukai K, Hirata E, Komatsu M and Kobayashi $\mathrm{H}$ : Predicting the chemosensitivity of ovarian and uterine cancers with the collagen gel droplet culture drug-sensitivity test. Anticancer Drugs 16: 525-531, 2005.

26. Inuyama Y and Takeda C: A cooperative phase II study of cisplatin in patients with head and neck cancer. Gan To Kagaku Ryoho 13: 232-238, 1986 (In Japanese).
27. Jacobs C, Lyman G, Velez-García E, Sridhar KS, Knight W, Hochster H, Goodnough LT, Mortimer JE, Einhorn LH, Schacter L, et al: A phase III randomized study comparing cisplatin and fluorouracil as single agents and in combination for advanced squamous cell carcinoma of the head and neck. J Clin Oncol 10: 257-263, 1992.

28. Inaba M, Kobayashi T, Tashiro T and Sakurai Y: Pharmacokinetic approach to rational therapeutic dose for human tumor-bearing nude mice. Jpn J Cancer Res 79: 509-516, 1988.

29. Inaba M: Pharmacokinetic approach to the improvement of clinical predictability in the preclinical test for antitumor agents. Gan To Kagaku Ryoho 18: 1449-1456, 1991 (In Japanese).

30. Geran RI, Greenberg NH, Macdonald MM, et al: Protocols against animal tumors and other biological systems. Cancer Chemother Rep 3: 51-57, 1972.

31. Kawamura M, Inoue $\mathrm{Y}$, Oyama $\mathrm{T}$ and Kobayashi $\mathrm{K}$ : Chemosensitivity test for uresectable non-small cell lung cancer. Nihon Geka Gakkai Zasshi 103: 229-232, 2002 (In Japanese).

32. Takamura Y, Kobayashi H, Taguchi T, Motomura K, Inaji $\mathrm{H}$ and Noguchi S: Prediction of chemotherapeutic response by collagen gel droplet embedded culture-drug sensitivity test in human breast cancers. Int J Cancer 98: 450-455, 2002.

33. Kondo T, lmamura $\mathrm{T}$ and lchibashi $\mathrm{H}$ : In vitro test for sensitivity of tumor to carcinostatic agents. Gan 57: 113-121, 1966.

34. Salomon SE, Hamburger AW, Soehnlen B, Durie BG, Alberts DS and Moon TE: Quantitation of differential sensitivity of human-tumor stem cell to anticancer drugs. N Engl J Med 298: 1321-1327, 1978

35. Kobayashi H: CD-DST (Collagen gel droplet embedded culture drug sensitivity test). Oncology Chemotherapy 16: 231-235, 2000.

36. Shintani S, Hino S, Nakashiro K and Hamakawa H: Clinical trial of chemotherapy identified according to chemosensitivity assay for oral cancer patients with unresectable recurrent lesions. Gan To Kagaku Ryoho 33: 357-360, 2006.

37. Rosell R, Taron M, Barnadas A, Scagliotti G, Sarries C and Roig B: Nucleotide excision repair pathways involved in Cisplatin resistance in non-small-cell lung cancer. Cancer Control 10: 297-305, 2003.

38. Reardon JT, Vaisman A, Chaney SG and Sancar A: Efficient nucleotide excision repair of cisplatin, oxaliplatin, and Bis-aceto-ammine-dichloro-cyclohexylamine-platinum(IV) (JM216) platinum intrastrand DNA diadducts. Cancer Res 59: 3968-3971, 1999

39. Takenaka T, Yoshino I, Kouso H, Ohba T, Yohena T, Osoegawa A, Shoji F and Maehara Y: Combined evaluation of Rad51 and ERCC1 expressions for sensitivity to platinum agents in non-small cell lung cancer. Int J Cancer 121: 895-900, 2007.

40. Simon GR, Sharma S, Cantor A, Smith P and Bepler G: ERCC expression is a predictor of survival in resected patients with non-small cell lung cancer. Chest 127: 978-983, 2005.

41. Fukushima M, Nomura H, Murakami Y, Shirasaka T and Aiba K: Estimation of pathways of 5-fluorouracil anabolism in human cancer cells in vitro in vivo. Gan To Kagaku Ryoho 23: 721-731, 1996 (In Japanese)

42. Sakamoto K, Sugimoto Y, Miyadera K, Oka T and Fukushima M: Preparation of anti-OPRT antibody for immunochemical detection. Gan To Kagaku Ryoho 32: 653-658, 2005 (In Japanese).

43. Ishida H, Shirakawa K, Ohsawa T, Sobajima J, Hayashi Y, Nakada H, Yokoyama M and Hashimoto D: Expression of mRNA levels of thymidilate synthase, dihydropyrimidine dehydrogenase, and orotate phosphoribosyltransferase of colorectal cancer-relationships among mRNA levels in association with response to 5-FU based treatment. Gan To Kagaku Ryoho 32: 1929-1934, 2005 (In Japanese)

44. Yamada T, Tanaka N, Yokoi K, Ishikawa N, Seya T, Kanazawa Y, Shirakawa T, Ohkawa K, Koizumi M, Ohaki Y, et al: Correlation between clinical pathologic factors and enzymatic activity of orotate phosphoribosyl transferase (OPRT), dihydropyrimidine dehydrogenase (DPD) and thymidylate synthase (TS) in colorectal cancer. Gan To Kagaku Ryoho 33: 789-793, 2006 (In Japanese).

45. Watanabe M, Satomi T, Matuda K, et al: Relationship between expression of enzymes activating fluoropyrimidine anti-tumor agents and response to the agents in oral squamous cell carcinoma. Japanese Journal of Head and Neck Cancer 34: 498-502, 2008 